térítéseit majd végül csak a kiváló egyháztörténész, bizantinista, patrisztikus, és egyúttal görögkatolikus pap, Baán István kutatta az 1990es évek közepén.

Tóth Gergely ugyan viszonylag tömören írt

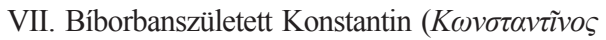

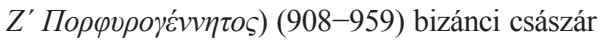

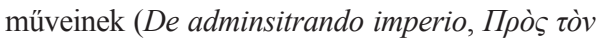

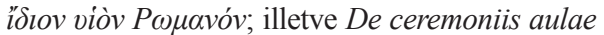

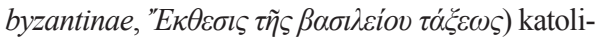
kus és protestáns értelmezéséről. A honi tudományosság egyébiránt már a 18. században felfigyelt Bíborbanszületett Konstantin müvének magyar őstörténeti és keleti vonatkozásaira. Előbb Kéri Borgia Ferenc (1702-1768) jezsuita páter, majd utóbb a már említésre került protestáns Schwarz Gottfried fedezte fel a bizánci császár művét, és vette górcső alá. Széles körben nem igazán volt ismert e két egyházi férfiúnak a nevezett témában történt vizsgálódása, illetve az sem volt köztudott, hogy kutatásaik milyen jelentős hatás gyakoroltak későbbiekben a magyar őstörténeti kutatásokra is. Példának okáért, a 19. század közepén Lukácsy Kristóf (1804-1876) szamosújvári örménykatolikus főplébános, és egyúttal armenológus-történész vette elő - többek között Kéri Borgia és Schwarz vizsgálódásai alapján Bíborbanszületett Konstantin császár müvét, és ő hívta fel a figyelmet elöször az úgynevezett szavárd (sewordi) kérdés esetleges magyar és örmény történeti vonatkozásaira. Jóllehet, Lukácsy kutatásai során ingoványos talajra tévedt azzal, hogy Bíborbanszületett Konstantin és a munkájával többé-kevésbé egykorú örmény krónikaírók - mint pl. V. „Történész” János (Yovhannēs Patmaban Drasxanakertac'i) (899-925) örmény egyházfő (katholikosz), Step'annos Tarōnec'i Asołik és Movsēs Dasxuranc'i - művei nyomán egy örmény-magyar nyelvrokonsági elméletet is kreált. Ennek az elméletnek ugyan nem sok követője és híve akadt, de Lukácsynak - Kéri Borgia és Schwarz kutatásaira alapozva - a szavárd kérdésben végzett kutatásai megkerülhetetlenné váltak. Sőt olyan történészek, filológusok, orientalisták vagy bizantinológusok, mint pl. Fiók Károly (1857-1915), Pecz Vilmos (1854-1923), Thúry József (1861-1906), Gyóni Mátyás (1913-1955), Moravcsik Gyula (1892-1972),
Czeglédy Károly (1914-1996), Harmatta János (1917-2004) és Szádeczky-Kardoss Samu (1918-2004) is figyelembe vették Lukácsy kutatásait.

Összefoglalva, Tóth Gergely munkája mindenképp alapmünek tekintendő. Munkásságán keresztül kiderült, hogy a könyvben említésre került teológusok és történetírók nagyban hozzájárultak egy modernebb, egységesebb és egyszersmind kézzelfoghatóbb Szent István- és Szent Korona-kép kialakításához. Ezen túlmenően teljes meggyőződéssel írhatjuk le azt is, hogy könyve megkerülhetetlen lesz a magyar őstörténeti, a magyar középkori, valamint koraújkori, és általonosságban véve is a magyar historiográfiai kutatásoknak. Ennek okán ne lepődjünk meg, hogy Tóth Gergely könyve kis idő múltán konstruktív vitákat fog gerjeszteni, illetve eredményezni, ami voltaképpen e könyvnek az egyik legfontosabb célkitüzése, még ha azt a szerző in concreto külön nem is nyomatékosította müvében. Végül, de nem utolsósorban azon se lepődjünk meg, hogy Tóth Gergely könyve előkelő helyett fog elfoglalni a tudományos közlemények hivatkozásaiban.

NAGY KornéL

Koncz Pál, Papírmívesség és könyvmüvészet Veszprém megyében a 18-20. században, Szerk. Jakab Réka, Veszprém, Laczkó Dezső Múzeum, 2017, 383 p. ill., $30 \mathrm{~cm}$

Koncz Pál összegyűjtött tanulmányait, közleményeit, kéziratban maradt restaurálási dokumentációit Jakab Réka szerkesztette kötetbe. Némely tanulmánya országos folyóiratban, például a Magyar Könyvszemlében jelent meg, de sokuk helyi lapokban, saját múzeumi kiadványként. Így csak esetlegesen voltak hozzáférhetők. Pedig Koncz Pál Veszprém és Pápa tágabb körzete papír- és könyvművessége majd három évszázados történetének a szakmai közönség számára is alig ismert részleteit tárta fel. Nemcsak a helytörténet művelői számára érdekesek írásai, hanem az egész hazai könyvkötéstörténetnek, sőt az egész könyves szakmának.

Koncz Pál (1951-2015), a Laczkó Dezső 
Múzeum restaurátora Hódmezővásárhelyen született. Zongorázni és hegedülni tanult az ottani Liszt Ferenc Zenei Általános Iskolában. 1966-70 között a budapesti Képző- és Iparmüvészeti Gimnáziumban tanult, s érettségizett papír-, bördíszműves és restaurátor szakon. Ezt követően másfél éven át szülővárosában, az Alföldi Porcelángyárban grafikusként dolgozott. 1972 őszétől nyugdíjazásáig - 1998-2012 között mint osztályvezető - müködött restaurátorként a veszprémi Bakony Múzeumban, ma Laczkó Dezső Múzeumban. 1979-ben diplomát szerzett a Magyar Képzőművészeti Főiskola tárgyrestaurátor szakán. Diplomamunkája „Egy 1567-ben nyomtatott wittenbergi Luther-Biblia konzerválása és restaurálása" volt. A jelen kötet negyedik egysége e munkájával kezdődik. 1990 után szakmai tanácsadóként több itthoni és erdélyi múzeum munkáját segítette. 2006ban elnyerte a Laczkó Dezső-díjat. Tagja volt a Pulszky Társaságnak, valamint a Papír- és Nyomdaipari Müszaki Egyesület Restaurátor Szakosztályának. A Pulszky Társaság Mütárgyvédelmi Tagozatától 2015-ben Balázsy Ágnes-díjban részesült. Tevékeny tagja volt a Veszprémben 1989-ben megalakult Orbán Balázs Alapítvány Kuratóriumának.

Kurátora volt az „Elötte / utána. - Restaurálás, mütárgyvédelem a Laczkó Dezső Múzeumban, 2009-2010” címü kiállításnak. A Múzeum állandó kiállítása: „Látványkönyvtár - Tudástár" címmel a tihanyi bencés apátság raktárába begyüjtött vegyes provenienciájú, általa ott válogatott könyvanyagból állt össze, amellett, hogy Koncz Pál szorgalmazta a meglévő, müködő bencés, ciszterci és ferences rendházaknak - a posszesszorbejegyzések alapján - őket illető könyvek visszaszolgáltatását.

Szakmai ismeretét és tapasztalatát 19802008 között megjelent cikkei őrzik maradandóan, s most ezek együttese ez az impozáns kötet. Négy egységre oszlik: 1. Veszprém megye mindhárom papírmalmának története; 2 . Veszprém megye könyvkötőmühelyei és könyvkötői; 3. Mủvelődéstörténeti, könyvtörténeti írások; 4. Restaurálás és mütárgyvédelem és -elmélet. Ez utóbbiak egy része korábban nem jelent meg. Leletmentésként fogható fel a kötet utolsó dol- gozata: Sirkövek a felsőörsi református temetöből, amely írás itt olvasható először. A szerző eredeti rajzai és fényképei technikailag megújított formában kerültek be a kötetbe, igen megnövelve a kiadvány értékét, élményt nyújtó mivoltát és szépségét.

1. Pápán a papírmalomhoz nélkülözhetetlen vizet a kiváló adottságú Tapolca-patak szolgáltatta. A hagyományos merített papírhoz szükséges, minőségileg és mennyiségileg megfelelő rongy beszerzését pedig az a körülmény segítette, hogy Pápa éppen az Ausztriába irányuló rongykivitel egyik dunántúli központja volt. A török hódoltság után Pápa és környéke az Esterházyak birtokába került. Az uradalmi adminisztráció mellett a közigazgatás, az egyházak és az iskolák voltak a jelentős papírfelhasználók. 1729-1755 között a pápai papírmalom tulajdonosa gróf Esterházy Ferenc volt. Az első árendátor-mester a németajkú Andreas Clauss (esetleg Gauss) volt. Ügyesen fejlesztette a malmot, s a maga hasznát is megtalálta, mivel idővel annyi tőkét tudott gyüjteni, hogy meg tudta vásárolni - bizonyos feltételekkel - a malmot, s múködtette 1766-ig. Az első pápai, egykori papírmalom müszaki jellemzőiről semmit nem lehet tudni, de azt igen, hogy jó minőségü és szép papirost gyártottak ott több mint három évtizeden keresztül. Koncz Pál e cikkeihez csatolja a vízjelrajzokat és ezek jegyzékét, továbbá épületalaprajzot, topográfiai térképeket és épületfotókat. A Pápához közeli Igal-pusztán indult meg 1829-ben a tulajdonképpeni második pápai papírmalom. Ennek alapítója, átépíttetője a tatai ághoz tartozó Esterházy Miklós. Az első árendás papírkészítő mester Gottfried (Caspar) Attorf (Atdorf), aki Sólyból, a zirci ciszterci apátság által ott létrehozott papírmalomtól szerződött át Igalba. Igen tanulságos az 1828ban kelt, majd 1829-ben kiegészített szerződés - itt magyar fordításban olvasható - szövege. (Az eredeti németül van, amint ez és az előző papírkészítő mester is németajkú volt. A török uralom alóli felszabadulást követően nagyon sokan telepedtek be német nyelvterületről az elnéptelenedett országba.) A papírmalom-építés befejezésekor készült pénzügyi kimutatás 
(„Bizonyítvány”) ipar- és gazdálkodástörténeti jelentősége óriási. Attorf mesteren kívül még három papírkészítő neve ismert. Koncz Pál közli még három - a malom vízszennyezésének kérdésével kapcsolatos - vármegyei akta rövidített szövegét 1832-ből. E két papírmalom öszszesen másfél évszázados működésének a hazai és külföldi gyáripar (pl. a Fiumei Papírgyár) óriási konkurenciája vetett véget.

A már említett sólyi papírmalom 17901851 között müködött. A 12. század végén gyökeret vert zirci ciszterci monostor a 16. században elpusztult. A 18. században építették és alapították újra. Bevételi forrásainak egyike éppen a sólyi papírmalom volt. Tájékoztatást kapunk a tanulmányban a bérleti szerződésekröl, az árendásokról, mesterekről és alkalmazottakról, a malom berendezéséről és készítményeiről. Érdekes színfoltot jelentenek a sólyi papírmalom felavatására írt köszöntőversek.

Ezt a részt három további papírral foglalkozó cikk egészíti még ki: Papirtörténeti adatok Pápáról, A papir vizjelek története és haszna és Papirtörténeti adatok, vizjelek Lékáról. Elismerésre méltók Koncz Pál helyi és országos levéltári forráskutatásai.

2. A második részben először a Veszprém Megyei Levéltárban őrzött, 1788. június 16-án kelt bizonyságlevélről olvashatunk, melyet Melchior Raithaler, a céhbeli legények atyamestere és Johann Echterling céhelöljáró állított ki Joseph Echterling budai születésű, 26 éves könyvkötőlegény számára. A vörös viaszpecsét szerint ekkor még együtt voltak a pesti és budai könyvkötők, felirata: SIGIL.DER.BVRGL.BVCHB. IN.OFEN.Ū.PEST.1729.

A Pannonhalmi Főapátsági Könyvtárba került a soproni fegyveres polgárőrség protokolluma. Díszes aranyozott bőrkötése 1791-ből való, ifj. Michael Gottlieb Schrabs munkája, fölül a magyar és alul Sopron város címerével. A kötésről közölt képek mellett a festett elözékpapírokból is láthatunk itt mintákat.

A 18. század közepétől Veszprémben és Pápán is egyre több könyvkötő telepedett meg. Nemcsak könyvet kötöttek, hanem bizományban átvett könyvekkel kereskedtek is.
A tankönyvek, kalendáriumok egyszerü kötése mellett a plébániák szerkönyvei kötésénél szinte minden díszítőszerszámukat bevetették. De különböző tokokat és ládikákat is készítettek. Személyük azonosításában segítenek fennmaradt könyvkötőszámlák, s olykor plébániák anyakönyvi adatai (pl. 124). Koncz Pál tekintélyes, mintegy 30 fós listát közöl a pápai és veszprémi mesterek, legények, továbbá két-két szentkirályszabadjai és várpalotai mester nevével (129-131). Az iskolázottság, az írni-olvasni tudás terjedésével, s ami ebböl következik, a könyvek iránti kereslet növekedésével, egyre több könyvkötő számára kínálkozott megélhetés. A lokalizálásban, azaz a kötések eredetének területi meghatározásában segítenek a környék papírmalmaiból származó előzékpapírok. A pápai gyüjteményekben érthetően gyakran akadnak Győrhöz köthető munkák is.

A pápai Zsoldos György és Szép Miklós, református kisnemesi származású könyvkötők, egy céhben dolgoztak a 18. század második felében. Müködésüket, családi viszonyaikat, azonosítható kötéseiket elemzi a szerző. Mindkét mester szerszámainak bélyegzőtáblázatát is közli. - Mayer Adolf a 19. század második felében tevékenykedett mint könyvkötő, papírés könyvkereskedő. A Függelékben az ő mintegy 20, ájtatos szövegü könyvhöz készített kötéséről tájékozódhatunk. Néhány kivételtől eltekintve (pl. a 14. számú kötés [169]), többségében kis nyolcadrét nagyságú, az egész táblát borító lemezzel nyomott, bőr-, félbőr- és vászonborítású, használati kötés.

Kis Tivadar pályája, könyvkereskedése és könyvkötészete, családi életvitele, utódai, jogot végzett Gábor fia és alkalmazottai, s különösen dr. Kiss Gáborné visszaemlékezése szociológiai dokumentum az 1940-es évek embertelen körülményeiről, előbb a háború, majd a politikai-hatalmi váltás okozta viszonyokról.

Kis Tivadar és Kiss Gábor mellett, a 20. századi pápai Rhédi Károly és Bedőcs József könyvkötőkről, továbbá egy ajkai nyomdászés könyvkötőmesterről, Imre Gézáról is olvashatunk. Nemcsak a díszítő eszközökről, hanem a szerszámkészletről is láthatunk képet a könyvben (195). Fontos eredmény, hogy egy 
több generáció használta szerszám-együttes bekerült a veszprémi Laczkó Dezső Múzeumba (187), s persze idevágó kézirat, jegyzőkönyv, s például a Veszprémi Mészáros céh rendszabásának 18. századvégi aranyozott barokk díszkötése is (205-206). Mindebben bizonyára Koncz Pálnak is része volt.

Koncz Pálnak sikerült részletesen feltárni a veszprémi Franz Gründler munkásságát (1760-1845) és Ludwig Georgi „könyvkötő és könyvárus" ugyanezen periódusból való könyvkötéseit, a díszítőszerszámok alapján azonosítva ezeket. Ez esetben is közzétette válogatott katalógusban e könyvek listáját. A bélyegzőket és görgetőket szemlélve igen vegyes képet kapunk, mert gótikus liliomtól, legyeződísz cikkelyen és barokk csavart indán át rokokó és neoklasszicista motívumokig, idevéve a hit-remény-szeretet szimbólumot jelképező motívumot és az áldozó kelyhet, minden elöfordul. Bizonyára ez esetben is több generáció, és több könyvkötő örökölt és megvásárolt szerszámai gyüjteményeként.

Imre Géza ajkai nyomdász és könyvkötő már a 20. század első felének mestere. A kutatási eredmények alapja az özvegy közlései, s a nála örzött dokumentumok. Ez is egyfajta leletmentés egy 1935-1944 és 1947-1949 között müködő nyomda felszereléséről is. Koncz leletfelvételeiből gyakran emberi sorstragédiáknak is tanúi lehetünk, párhuzamosan a kis iparénak a „nagy” történelem folyamatában. (1945-ben megsemmisült a nyomda, a keserves újrakezdés után1949 végén államosították, s a megpróbáltatások ezzel még nem értek véget.)

3. A „Művelődéstörténet” címet viselő rész a Laczkó Dezső Múzeum egy ősnyomtatványa (Johannes de Magistris: Quaestiones, Velence 1487.) ismertetésével kezdődik. Nagyon fontos híradás, mert ebből a kiadásból nincs más példány Magyarországon, sem a hazai országos ősnyomtatvány-katalógus (CIH) összeállítói nem értesültek róla, sem a világkatalógusban (ISTC im00026000) ez a példány nem szerepel. Ezt majd jelenteni kell a londoni és berlini központba. - A reneszánsz könyvkultúra emlékei Veszprémben és környékén címü tanulmány az egykori lövöldi karthauziak és vázsonyi pálosok szétszóródott, másutt őrzött (OSZK, MTA KIK, Esztergomi Főszékesegyházi Kvt., Győr, Egyházmegyei Kvt.) még meglévő korai könyveit, kódexeket és ősnyomtatványokat vesz számba. Kiemelkedő jelentőségü a veszprémi Érseki Könyvtárban található Lucanus: Pharsalia, Róma 1469. ősnyomtatvány. E tanulmányban is említi a szerző az előbbi, a Laczkó Dezső Múzeum Johannes de Magistris-féle ősnyomtatványát. Egy másik, antikváriumból beszerzett ősnyomtatványuk, Thuróczy János brünni kiadású Chronica Hungaroruma, szintén nem szerepel a CIH-ben. Ebböl egyébként másfél tucat példány van magyar közgyüjteményekben.

4. Ez a rész Koncz Pálnak a „Restaurálás és mütárgyvédelem" körébe tartozó írásait öleli fel. A budapesti könyvbemutatón (2018. március 26-án) az előző részekről jómagam, Koncz Pál pályájáról és erről a 4. részről kolléganője, Ludvai Zsuzsanna, a Laczkó Dezső Múzeum papír- és bőrrestaurátora beszélt. Hangsúlyozta Pali sokoldalúságát és szakszerüségét, nyitottságát az új eljárások iránt. Nemcsak bőrés papír-, de csontból, fából és kőből készült tárgyakat is restaurált. És nemcsak restaurált régészeti leleteket, hanem aktívan részt vett régészeti ásatásokon. Legfontosabb mondatának én azt tartom, hogy a restaurálás folyamán „kompromisszumot kell kötnünk a beavatkozás mértékéről” (319).

A kötetet epilógus zárja, amelyben sírkövekről olvashatunk, s látunk rajzokat a felsőörsi református temetőből. A szerzőre jellemző kitekintéssel, s a szép iránti fogékonysággal, a hagyományokkal szembeni tisztelettel közli 34 sír leírását, de 37 sírkő rajzát. Elismeréssel kell adóznunk Koncz Pál grafikusi tehetségének.

Köszönettel tartozunk, a támogatók mellett, a Laczkó Dezső Múzeumnak és a szerkesztőnek e kötet létrehozásáért, hogy Koncz Pálnak munkásságát folyamatosan dokumentáló s elszórtan megjelent cikkeit, tanulmányait ily módon könnyen hozzáférhetővé tették.

Az apróbb hibák nem vonnak le a könyv érdemeiből. A 102. oldalon kimaradt a 7. lábjegyzet (a velin papírról), s ami ott a 7. sor- 
számon van, az a 8 . hivatkozáshoz tartozik. A 115. oldalon a cikk 2-3. sorában Joseph Echetering, lejjebb Johann Echterling nevét olvassuk. Feltehetően apáról és fiúról van szó, de a családnevük azonos kell legyen, s a közölt bizonyságlevél fotóján megbizonyosodhatunk arról, hogy az Echterling alak a helyes. Ugyanitt a kövérrel szedett pecsétfeliratból kimaradt a 'BVCHB' szó, s 'IN'a helyes, nem im Ofen. Az országos ősnyomtatvány-katalógus (Sajó-Soltész: CIH) a bibliográfiában kétszer egymás után szerepel, a második leírás a jobb, bár hiányolom - nemcsak itt, hanem általában mindenütt -, hogy a másik két közremüködőt, Csapodi Csabát és Vértesy Miklóst ki szokás hagyni, holott az elöbbi az MTA KIK, az utóbbi az ELTE EK ősnyomtatványait gyűjtötte össze és írta le, s ezek az összállomány harmadát teszik ki.

A szakkifejezéseket illetően kérem a kollégákat, hogy 'arctábla' helyett használjuk egységesen az 'elötábla' (és háttábla = Vorder- und Hinterdeckel, upper and lower cover) megnevezést, s a klisé helyett a lemez (= Platte, vagy angolul plate) elnevezést, amint a nemzetközi, Berlinben szerkesztett kötés adatbázisban (EBDB = Einbanddatenbank) is használják. (Gustav Moessner, Buchbinder ABC... 1981ben megjelent kötetében a 'Klischee' címszó alatt ki is mondja, hogy 'a könyvkötők nem beszélnek kliséről, hanem lemezről...”), - A 'másodlagos kötés' nem egy adott könyv második, esetleg harmadik kötése - ha a könyvet elhasználódás miatt újra kellett füzni és kötni -, hanem egy történeti kötés újbóli felhasználása egy másik könyv bekötésére, archaizáló hatás céljából. Ez a 19. század végén sajnos gyakorlatban volt, adott esetben nyelvemlékek és ősnyomtatványok értéknövelése okán és a rosszul értelmezett korhüség jegyében.

Koncz Pál cikkei, tanulmányai így összegyüjtve nagy nyereség a magyar kötéstörténet 18-20. századi Veszprém megyei anyagának ismeretéhez, még akkor is, ha a szerzőnek már nem volt alkalma összefésülni gyüjtött nagy anyagát, így az egyes cikkekben elkerülhetetlenül vannak ismétlések. Könyvében, miként a vízjelek rajzai, a kötések bélyegzőinek, gör- getőinek és lemezeinek levonatai, illetve ezek jó minőségủ reprodukciói forrásértékủek.

\section{Rozsondai MarianNe}

„Kezembe vészem, olvasom és arról elmélkedem", Emlékkönyv Fekete Csaba születésének 75. és könyvtárosi müködésének 50. évfordulójára, Szerk. Gáborjáni Szabó Botond, Oláh Róbert, Debrecen, Tiszántúli Református Egyházkerületi Gyüjtemények (A Tiszántúli Református Egyházkerületi Gyüjtemények Kiadványai), 2015.

Kétszeres ünnep adta a most bemutatandó tanulmánykötet apropóját: Fekete Csaba, a Tiszántúli Református Egyházkerületi és Kollégiumi Nagykönyvtár tudományos fömunkatársa, teológus, himnológus, mủvelődéstörténész 2015ben ünnepelte 75 . születésnapját és könyvtárosi pályafutásának 50. évfordulóját. Aki ismeri az ünnepelt munkásságát, tudja, hogy Gáborjáni Szabó Botond kicsit sem túloz, amikor megállapítja, hogy kollégája (,,a református egyház talán utolsó polihisztora”) ,publikációival egyedül pótol egy kisebb kutatóintézetet”. S valóban, Fekete Csaba sokoldalúságát mi sem jelzi pontosabban, mint a kötet végén közölt, igen impozáns válogatott bibliográfia. Ez a lista ugyan nem tartalmazza Fekete Csaba előadásainak többségét, a napilap- és folyóiratcikkeinek egy részét, valamint a kiállítási megnyitókat, előszavakat, lektori és opponensi véleményeket, de így is majdnem 220 tételből áll, amelyek a biblika-teológia, az egyház-, az irodalom-, a könyv- és könyvtártörténet, a könyvmúvészet, a liturgia, a himnológia és az egyházzene területére kalauzolják olvasójukat. A Festshriftben helyet kapó tanulmányok tematikai sokszínüségét magyarázza, hogy alkotóik ezzel a gazdag életművel folytatnak dialógust, több szálon is reflektálva az ünnepelt kutatási eredményeire. A köszöntő kötet Gáborjáni Szabó Botond bevezető laudációja (Ösztönösség és fegyelem), valamint a fent említett bibliográfia (Fekete Csaba fontosabb kiadványai és tanulmányai (válogatás), A szerzö annotációival) közt öt fejezetre oszlik. 